\title{
ELEVATED HIGHWAY: A Solution to Developmental Problems in Pathanamthitta
}

\author{
Subhalekshmi ${ }^{1}$, Anandu R Pillai ${ }^{2}$, Anaswar Das $\mathrm{H}^{3}$, Pavishi $\mathrm{P}^{4}$, Senu Daison ${ }^{5}$ \\ ${ }^{1}$ Asst. Professor, ${ }^{2345}$ Student \\ Civil Department, \\ Musaliar College of Engineering \& Technology, \\ Pathanamthitta.
}

\begin{abstract}
An elevated highway is a highway that is raised above grade for its entire length. It has restricted entry and exit. Technically the entire highway is a single bridge. The Omalloor - Kaipattoor road is a major road in Pathanamthitta district which is also a part of NH183A which spans all the way from Kollam to Vandiperiyar via Pathanamthitta and Adoor. Almost 17 sub roads that came from other towns and cities connect the main road at Omalloor itself. Traffic congestion occurs during peak hours in Omalloor - Kaipattoor route. During the flood that occurred in the year 2018-2019, almost all the major roads were flooded with water. The water logging has caused the roads to lose its strength and durability. The lands in Pathanamthitta have hilly areas and plain marshy land. Land available for future road widening or construction is very less in Omalloor area due to the marshy land of the area. So we have proposed an elevated highway at Omalloor Kaipattoor road for smooth traffic flow.
\end{abstract}

Keywords: Elevated highway, Traffic volume survey, Questionnaire survey, Total station survey.

\section{INTRODUCTION}

Pathanamthitta is a well-known district in Kerala for its culture and heritages. There are famous places like Sabrimala, Pandalam, Aranmula, Thiruvalla, etc. Pathanamthitta is among developing districts of Kerala. The district has a population density of 453 inhabitants per square kilometer.

Omalloor is one of the small towns in Pathanamthitta district. Omalloor is well known for its temples. Omalloor is one of those places where almost 17 sub roads from different towns and cities connect NH183A.

The increased traffic congestion in this area has been increased since last decade. An option for a bypass road cannot be taken in this case as the area gets flooded with water and also there is no land available for future development.

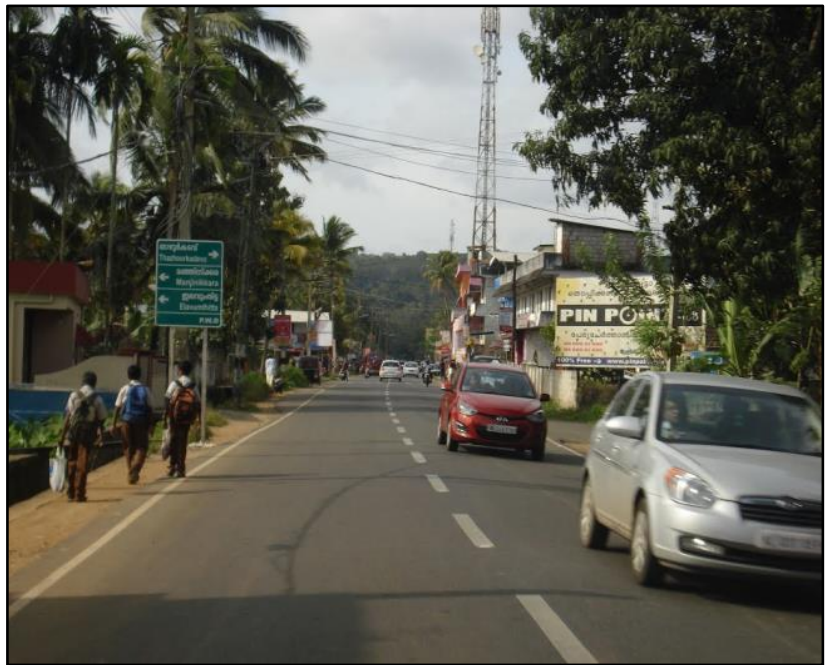

Fig.1 Omalloor - Kaipattoor road

\section{OBJECTIVES}

- To identify and analyze the present scenario of traffic congestion at Omalloor - Kaipattoor road.

- To conduct traffic volume survey and questionnaire survey.

- Collect necessary data for elevated highway design.

- Analyze the data obtained.

\section{METHODOLOGY}

Basic data regarding the project were collected from concerned authorities like land availability, soil investigation details, etc. A traffic volume study was conducted near Government Higher Secondary School (GHSS), Omalloor and Uzhuvathu Devi Temple, Omalloor. A detailed questionnaire survey was also conducted to evaluate the public interest about implementation of this project. The alignment of the existing road was found out by conducting a total station survey.

The accurate data regarding soil investigation couldn't be collected due to some financial causes. Thus the soil investigation details of Pathanamthitta KSRTC bus stand has been adapted, as the land near KSRTC bus stand is same as that of the land proposed for elevated highway construction at Omalloor. 


\section{DATA COLLECTED}

As a part of study, the following data were collected.

\section{A. Soil investigation}

It is the study conducted to know about the structure and property of land underneath. The proposed site at Omalloor and the Pathanamthitta KSRTC bus stand side have the same type of soil. The average of soil investigation reports at the Pathanamthitta KSRTC bus stand side shows

- $4.10 \mathrm{~m}$ of filled lateritic soil and quarry waste (brown) $(0.00 \mathrm{~m}-4.10 \mathrm{~m})$

- $1.50 \mathrm{~m}$ of lateritic gravel (red/yellow) (4.10m $5.60 \mathrm{~m})$

- $4.20 \mathrm{~m}$ of lateritic clay with sand \& gravel (yellow/red) $(5.60 \mathrm{~m}-9.80 \mathrm{~m})$

- $6.40 \mathrm{~m}$ of silty lateritic clay with sand (white/yellow) $(9.80 \mathrm{~m}-16.20 \mathrm{~m})$

- $1.20 \mathrm{~m}$ of silty weathered (white/grey) (16.20m $17.40 \mathrm{~m})$
- $6.80 \mathrm{~m}$ of soft rock (white/grey)

$(17.40 \mathrm{~m}-$ $24.20 \mathrm{~m})$

- $1.50 \mathrm{~m}$ of hard rock (grey) $(24.20 \mathrm{~m}-25.70 \mathrm{~m})$

Bore-hole terminated at $25.70 \mathrm{~m}$ depth and not met ground water level.

\section{B. Traffic volume survey}

It is the type of survey conducted to know the amount of traffic flow in any area. Traffic volume survey was conducted on a working day (24/10/2019) and on a weekend day $(27 / 10 / 2019)$ at two points i.e. near Government Higher Secondary School (GHSS), Omalloor and Uzhuvathu Devi Temple, Omalloor. Number of vehicles in each hour is estimated. Vehicles are categorized as bus, truck, car, two wheeler and light carriage vehicles. The numbers of vehicles are converted into PCU (Passenger Car Unit) and the average of the data is determined.

Passenger Car unit is calculated using the following data in TABLE 1.

TABLE 1. DIFFERENT VEHICLE PCU VALUE

\begin{tabular}{|l|c|}
\hline \multicolumn{1}{|c|}{ Type of vehicle } & Passenger Car Unit (PCU) \\
\hline Bus & 5 \\
\hline Truck & 4 \\
\hline Car & 1 \\
\hline Two wheeler & 0.4 \\
\hline Light carriage vehicles & 2 \\
\hline
\end{tabular}

TABLE 2. AVARAGE TRAFFIC VOLUME DATA

\begin{tabular}{|c|c|c|c|c|}
\hline \multirow[b]{2}{*}{ HOUR } & \multicolumn{2}{|c|}{ WORKING DAY (in PCU) } & \multicolumn{2}{|c|}{ WEEKEND DAY (in PCU) } \\
\hline & Near GHSS, Omalloor & $\begin{array}{c}\text { Uzhuvathu Devi Temple, } \\
\text { Omalloor }\end{array}$ & Near GHSS, Omalloor & $\begin{array}{c}\text { Uzhuvathu Devi Temple, } \\
\text { Omalloor }\end{array}$ \\
\hline 6am - 7am & 320.2 & 424.2 & 351.6 & 342.2 \\
\hline 7am-8am & 390.4 & 442.8 & 400.2 & 392.6 \\
\hline $8 a m-9 a m$ & 479.8 & 482.4 & 421.6 & 424.8 \\
\hline 9am - 10am & 560.8 & 522.2 & 450.4 & 472.6 \\
\hline 10am - 11am & 432.8 & 418.8 & 507.6 & 508.6 \\
\hline $11 \mathrm{am}-12 \mathrm{pm}$ & 395.6 & 398.2 & 403.4 & 419.6 \\
\hline $12 \mathrm{pm}-1 \mathrm{pm}$ & 345.8 & 379.8 & 339.2 & 374.8 \\
\hline $1 \mathrm{pm}-2 \mathrm{pm}$ & 317.6 & 394.2 & 330.6 & 330.4 \\
\hline $2 p m-3 p m$ & 377.2 & 415.2 & 352.4 & 300.8 \\
\hline $3 p m-4 p m$ & 434.8 & 461.6 & 421.4 & 350.2 \\
\hline $4 \mathrm{pm}-5 \mathrm{pm}$ & 542.2 & 556.2 & 458.8 & 428.6 \\
\hline $5 \mathrm{pm}-6 \mathrm{pm}$ & 519.2 & 506.8 & 504.8 & 503.8 \\
\hline
\end{tabular}




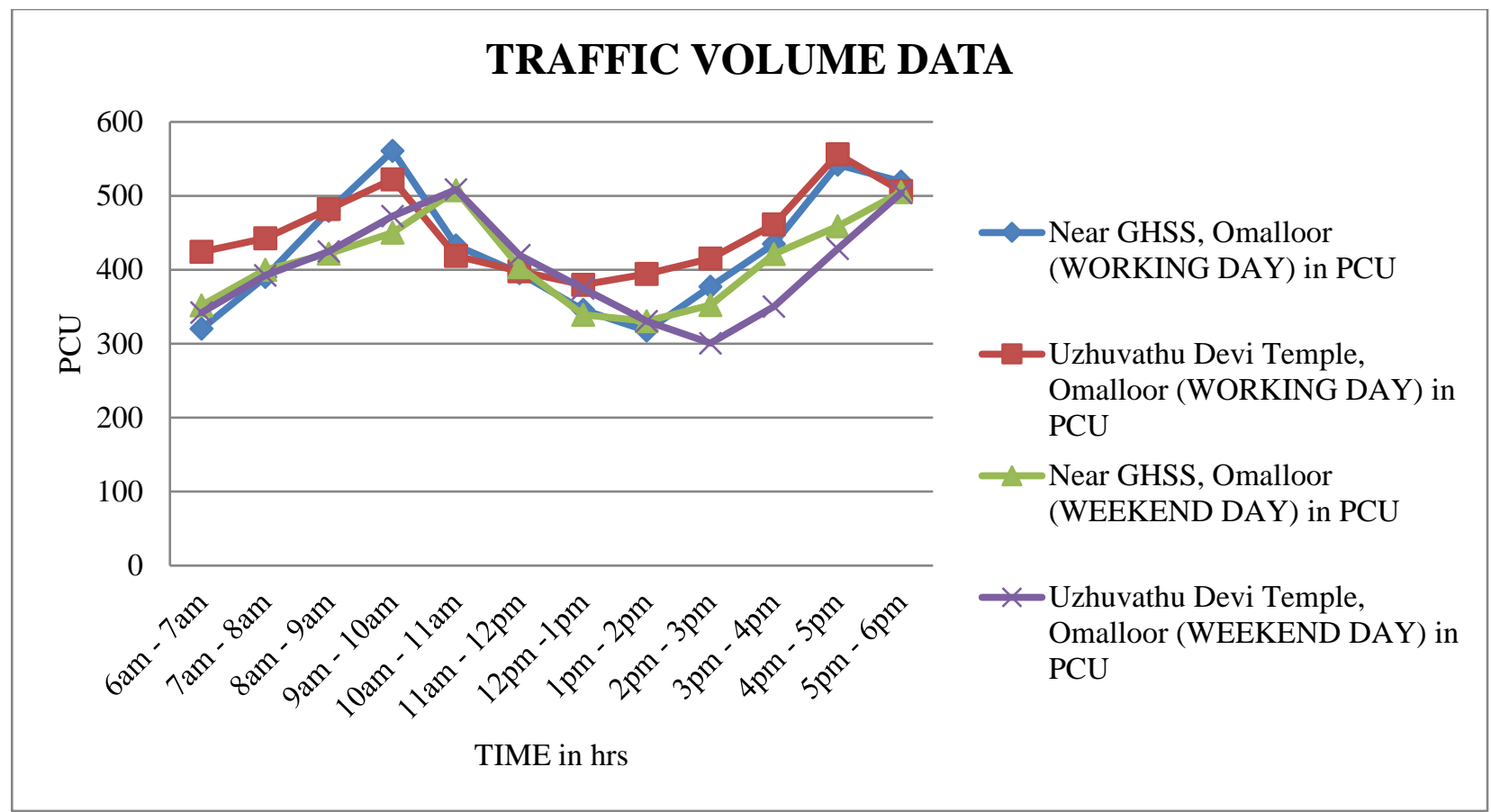

Fig.2 Traffic volume data

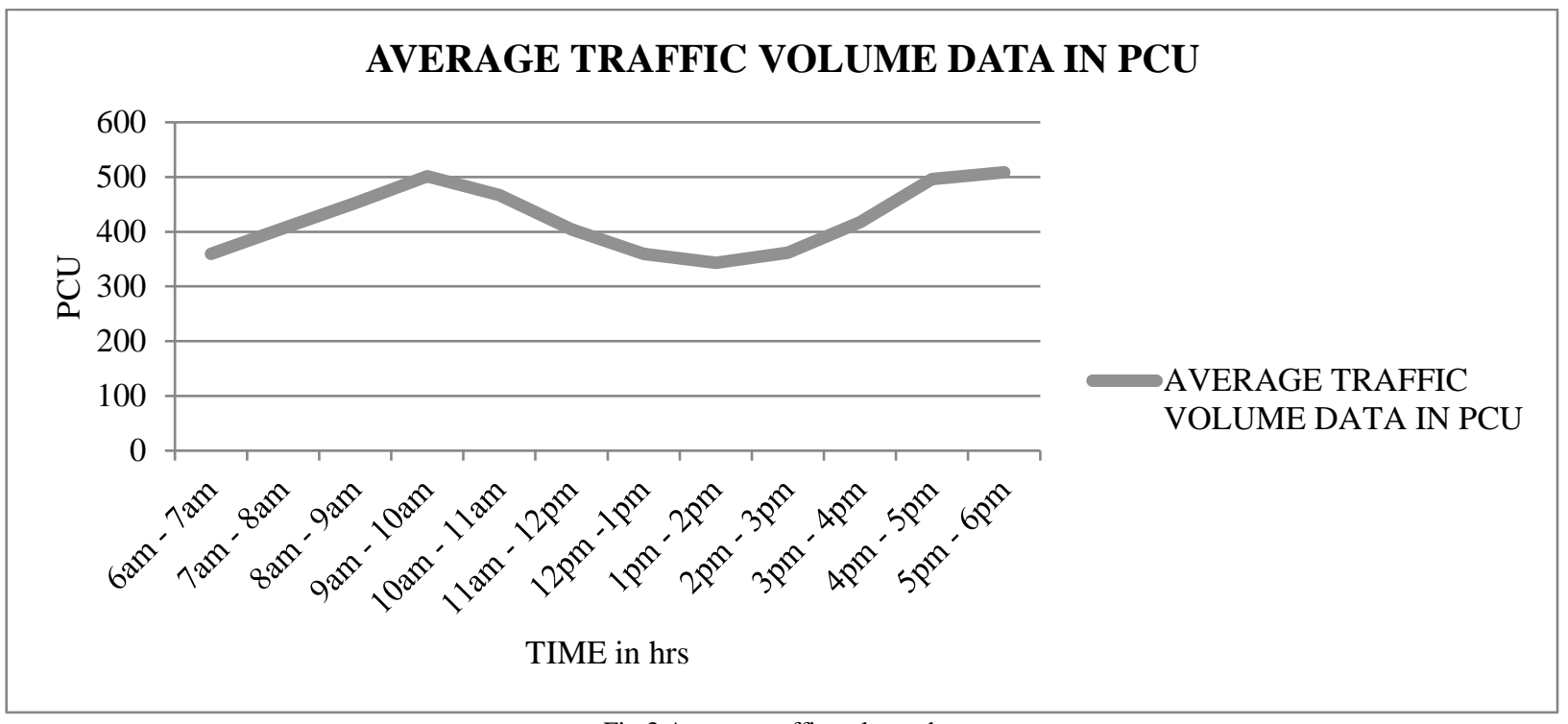

Fig.3 Average traffic volume data

\section{Questionnaire survey}

The questionnaire survey was conducted over the Omalloor - Kaipattoor road. The people included for the survey were pedestrians, nearby households and regular vehicle users. A questionnaire was prepared and distributed among the above mentioned people. And their feedbacks were collected. Almost $90 \%$ of people liked the proposed project of elevated highway. The average of the rating for the proposed project was calculated to be 8.68 out of 10 .

Some of the reasons that the people liked this project are:

$>$ Time required to travel the destinations will be reduced.

$>$ Rate of accidents would be considerably reduced.

$>$ Traffic congestions in this area will be reduced.

Some of the reasons that the people disliked this project are:
$>$ Large area of land will be acquired back by the government for this project.

$>$ Traffic conjunctions during construction phase.

D. Total station survey

Total station is surveying equipment which has a combination of Electromagnetic Distance Measuring Instrument and electronic theodolite. 


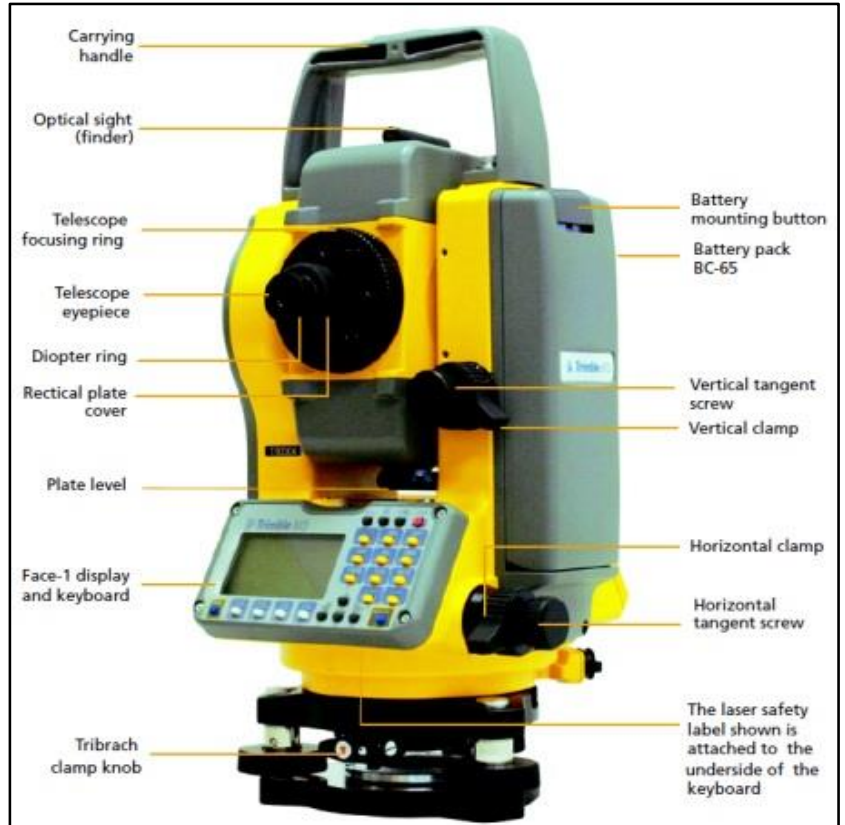

Fig.4 Total station survey equipment

Total station survey was done to determine the alignment of the existing road. Following steps were followed for total station survey:

- Tripod setup

- Mount instrument on tripod

- Instrument centering

- Instrument levelling

- Electronically verify levelling

- Set the instrument to north

- Set a default coordinate to the instrument station

- Take readings

- Shift to next known coordinate

- Back site to the previous instrument station

\section{RESULT AND ANALYSIS}

The elevated highway was designed and analyzed using software. All the specifications and dimensions were provided according to IRC specifications.

- Clarence from buildings $-5 \mathrm{~m}$

- Width of elevated road $-7.5 \mathrm{~m}$ (2 lane)

- Width of service road - 4.5m (1 lane)

- Pillar height $-5 \mathrm{~m}$

- Pillar diameter $-1.5 \mathrm{~m}$

- Slab thickness $-0.3 \mathrm{~m}$

- Width of crash barrier $=450 \mathrm{~mm}$ (IRC 5:1998)

- Wearing coat $=100 \mathrm{~mm}$

- Material: Concrete : M30

$$
\text { Steel : Fe500 }
$$

- Loading : Class AA

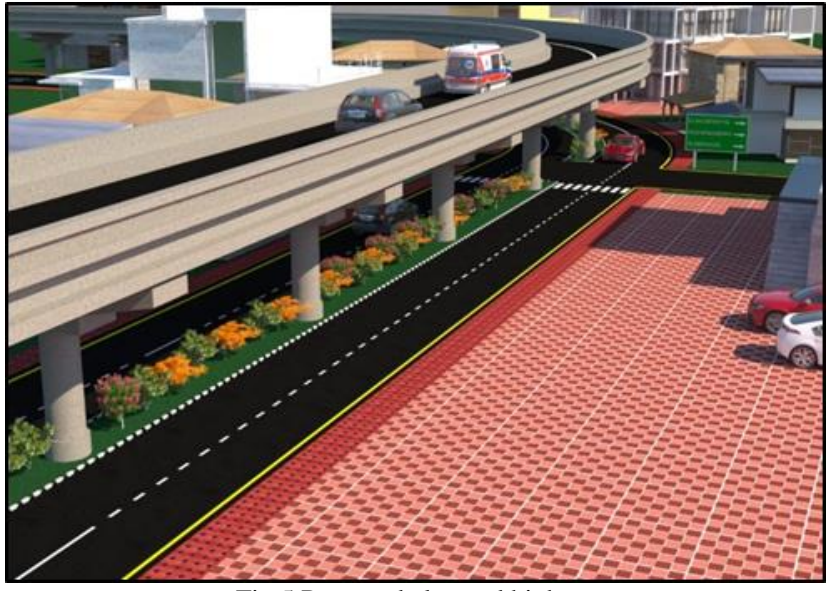

Fig.5 Proposed elevated highway

\section{CONCLUSION}

$>$ The present situation of traffic conjunction is thoroughly studied.

$>$ The surveys conducted are traffic volume survey, questionnaire survey and total station survey.

$>$ The proposed project could help rectify the traffic conjunction problems at Omalloor - Kaipattoor road thus allowing smooth flow of traffic.

$>$ The proposal can be adapted for the infrastructural as well as developmental improvement of the district.

\section{REFERENCE}

[1] Nidhi P Tiwari; Sumit Jaidiya; Trishala Shinde; Kalyani Dhoble; Nayan Korde; Achintya Sakhre; "Advanced Techniques used in Surveying”, IJRASET, volume 6, Issue III, March 2018.

[2] Abrar Ul Haq Bhat; Dr. Rakesh Gupta;, "A Review Paper on Study of Traffic Volume and its Safety Measures on National Highways", IRJET, volume 05 Issue 07, July 2018.

[3] Mohd. Sajid Ali; Bipin Kumar Singh;, "Future Trends and Developments in Bridge and Flyover Construction", IJTRE, volume 4, Issue 9, May-2017.

[4] Vighnesh R; Prabhath Ranjan Kumar S; Dhinesh Kumar P; Kishore Kumar S; Anand Kumar P K; " "Serviceability of Gandhipuram Flyover - Coimbatore", IJEAT, volume 8, Issue 5, June 2019.

[5] Ch.Manoghna; Shivangi Bharadwaj; "Design of Flyover Bridge", IJR, volume 04, Issue 14, November 2017.

[6] Rasheed Saleem Abed;, "Experience on Using Total Station Surveying for Mapping and Contouring”; IJCIET Vol. 4, Issue 3, 2013. 